Sawala - Jurnal Administrasi Negara

ISSN: 2598-4039 (Online)

ISSN: 2302-2221 (Print)

Volume 9 Number 2 December 2021

Page $168-178$
Copyright (C) 2021, Jonathan Jacob Paul Latupeirissa,

I Putu Darma Wijaya, dan I Made Yuda Suryawan.

This is an open access article under the CC-BY NC-SA

license

http:// DOI 10.30656/sawala.v9i2.3496 to this article

\title{
PROBLEMATIKA PELAKSANAAN KEBIJAKAN OTONOMI KHUSUS KEPADA DAERAH PAPUA DAN PAPUA BARAT DENGAN PERSPEKTIF KEBIJAKAN PUBLIK
}

Jonathan Jacob Paul Latupeirissa ${ }^{1 *}$, I Putu Darma Wijaya ${ }^{2}$, dan I Made Yuda

\section{Suryawan $^{3}$}

1,2Universitas Pendidikan Nasional, Denpasar, Bali - Indonesia

${ }^{3}$ Universitas Teknologi Indonesia, Denpasar, Bali - Indonesia

\begin{abstract}
The concept of special autonomy basically has two objectives: reducing the conflict of separatism and improving welfare from disparities with other regions. The prolonged conflict in Papua has brought several multidimensional adversities which tend to be neglected. The people in Papua experience the most loss. This article aims to analyze the problems with the particular autonomy policy in Papua and West Papua Provinces. The research uses a qualitative approach. Sources of data used come from analysis sourced from various kinds of literature such as books and journals. The description found in this research shows that the implementation of special autonomy has not been effectively and efficiently implemented. Indicators of the success of public services and conflict resolution are still far from concept. To conclude that granting special autonomy cannot necessarily be implemented pragmatically, the government needs to take humanist approaches that prioritize humanity.
\end{abstract}

\section{Abstrak}

Konsep otonomi khusus pada dasarnya memiliki dua tujuan, yakni untuk meredam konflik separatisme dan untuk meningkatkan kesejahteraan dari kesenjangan dengan daerah lain. Konflik berkepanjangan di Papua membawa sejumlah keterpurukan multidimensi yang cenderung terabaikan. Kerugian yang paling dirasakan dialami oleh masyarakat di Papua. Artikel ini bertujuan untuk menganalisa problematika kebijakan otonomi khusus di Provinsi Papua dan Papua Barat. Pendekatan yang digunakan menggunakan pendekatan kualitatif. Sumber data yang digunakan berasal dari penelitian bersumber dari berbagai literatur seperti buku dan jurnal. Gambaran yang ditemukan dalam artikel ini memperlihatkan bahwa pelaksanaan otonomi khusus masih belum secara efektif dan efisien dilaksanakan. Indikator keberhasilan pelayanan publik dan penyelesaian konflik masih jauh dari kata ideal. Sehingga memberikan kesimpulan bahwa kebijakan pemberian otonomi khusus tidak serta merta dapat dilaksanakan secara pragmatis, pemerintah perlu melakukan pendekatan-pendekatan yang humanis mengedepankan rasa kemanusiaan.

Kata kunci: Otonomi Khusus, Kebijakan Pemerintah, dan Desentralisasi Asimetris
Keywords:

Special Autonomy; Government Poli Asymmetric Decentralization.

Article History:

Submission July 112021

Revised October 302021

Accepted November 072021

Published December 012021

Corresponding Author

Email:

jonathan.latupeirissa@gmail.com 
Sawala - Jurnal Administrasi Negara

ISSN: 2598-4039 (Online)

ISSN: 2302-2221 (Print)

Volume 9 Number 2 December 2021

Page $168-178$
Copyright (C) 2021, Jonathan Jacob Paul Latupeirissa,

I Putu Darma Wijaya, dan I Made Yuda Suryawan.

This is an open access article under the CC-BY NC-SA

license

http:// DOI 10.30656/sawala.v9i2.3496 to this article

\section{PENDAHULUAN}

Penerapan konsep desentralisasi asimetris memberikan perlakuan khusus kepada daerah dengan derajat status yang berbeda dengan dengan daerah lain berdasarkan aspek kekhususan dan keistimewaan. Hal ini dikarenakan Indonesia adalah negara yang sangat majemuk yang sangat kompleks (Jamal \& Mara, 2018). Bentuk konkrit dari kebijakan desentralisasi asimetris di Indonesia dijalankan oleh beberapa daerah, seperti: bentuk daerah khusus seperti Daerah Khusus Ibukota Jakarta; daerah istimewa seperti Daerah Istimewa Yogyakarta, dan model otonomi khusus seperti Daerah Otonomi Khusus Papua, Papua Barat, dan Aceh (Nyimas Latifah Letty Aziz, 2018).

Kebijakan otonomi khusus pada dasarnya bagian yang tidak dapat dilepaskan dengan upaya pendesentralisasian kewenangan (politik), dengan diikuti desentralisasi kelembagaan, ditambah dengan bantuan keuangan (fiskal) melalui dana alokasi khusus untuk menjamin kebutuhan daerah otonomi khusus terpenuhi (Suryani et al., 2020). Praktik penyelenggaraan otonomi khusus telah dijamin oleh konstitusi Indonesia. Pasal 18B Undang-Undang Dasar Negara Republik Indonesia Tahun 1945 (UUD NRI Tahun 1945) menyatakan, "Negara mengakui dan menghormati satuan-satuan Pemerintah Daerah yang bersifat khusus atau bersifat istimewa yang diatur dengan undang-undang. Prinsip yang dijamin oleh pasal 18B ayat (1) UUD NRI Tahun 1945 adalah menjamin pluralisme antar daerah dalam bingkai negara kesatuan (Alivia, 2019). Salah satu yang mendapatkan perhatian yang besar dari pemerintah pusat adalah Provinsi Papua dan Papua Barat. Penerapan otonomi khusus pada dasarnya dapat dimaknai sebagai komitmen memberikan aspek kemanfaatan seluruh masyarakat, dan memperhatikan kelompok-kelompok yang termarjinalkan untuk mendapatkan perhatian khusus (Marit \& Warami, 2018). Dasar hukum dari pelaksanaan otonomi khusus dengan disahkannya Undang-Undang Nomor 21 Tahun 2001 tentang Otonomi Khusus Papua, menjadi instrumen legal dan memberikan jaminan fasilitas politik penyelenggaraan pemerintahan khusus di Papua (Pratomo, 2021).

Status pemberian otonomi khusus kepada Papua dilatarbelakangi dari empat akar permasalahan yang serius, diantaranya: Pertama, proses integrasi wilayah Papua ke Indonesia pada tahun 1964, diyakini masih banyak elit lokal yang masih menghendaki untuk menjadi negara sendiri. Pasca tahun 1964 muncul gerakan-gerakan separatisme yang menghendaki untuk memisahkan diri dari Negara Kesatuan Republik Indonesia (NKRI); kedua, terjadinya pelanggaran hak asasi manusia (HAM) yang dilakukan oleh negara sehingga mengakibatkan konflik berkepanjangan diakibatkan trauma dan dendam; ketiga, kegagalan pemerintah membangun bidang pendidikan, kesehatan, dan pemberdayaan ekonomi rakyat; dan keempat, marginalisasi dan diskriminatif arus migrasi (Mustikawati \& Maulana, 2020). 
Sawala - Jurnal Administrasi Negara

ISSN: 2598-4039 (Online)

ISSN: 2302-2221 (Print)

Volume 9 Number 2 December 2021

Page $168-178$
Copyright $@$ ( 2021, Jonathan Jacob Paul Latupeirissa,

I Putu Darma Wijaya, dan I Made Yuda Suryawan.

This is an open access article under the CC-BY NC-SA

license

http:// DOI 10.30656/sawala.v9i2.3496 to this article

Namun sejak awal implementasi kebijakan otonomi khusus banyak elit politik lokal yang kebijakan ini tidak akan membawa banyak perubahan bagi masyarakat Papua. Ada beberapa faktor penyebab masyarakat Papua skeptis terhadap kebijakan otonomi khusus, antara lain: Pertama, pemerintah pusat dalam menyelesaikan konflik di Papua belum melakukan pendekatan dialog yang yang maksimal; kedua, regulasi penerapan otonomi khusus sendiri dirancang belum mengakomodir hak-hak substansial masyarakat Papua; ketiga, penyelesaian problematika pelanggaran hak asasi manusia (HAM) yang tidak tuntas; keempat, masyarakat lokal merasa tersisih lantaran arus migrasi masuk di Papua; kelima, kesenjangan dan kemiskinan belum diatasi secara maksimal (Kharisma et al., 2020).

Selain penerima status otonomi khusus, pemerintah memperkuat perhatian kepada Papua dengan mempercepat pembangunan ekonomi lewat Peraturan Presiden Nomor 5 Tahun 2007 tentang Percepatan Pembangunan Papua dan Papua Barat, serta Peraturan Presiden Nomor 65 Tahun 2011 tentang Pembentukan Unit Percepatan Pembangunan Papua dan Papua Barat, dan Peraturan Presiden Nomor 66 Tahun 2011 tentang Rencana Aksi Percepatan Pembangunan Papua dan Papua Barat (Kharisma et al., 2020).

Namun sejauh ini kebijakan otonomi khusus yang diberikan di Papua dan Papua Barat masih jauh dari harapan. Kebijakan otonomi khusus ditambah dengan serangkaian regulasi untuk menstimulasi diharapkan untuk dapat mewujudkan keadilan dan kesejahteraan masyarakat yang merata berdasarkan karakteristik daerah, budaya, agama, dan historis. Namun justru sebaliknya otonomi khusus belum mampu mengatasi permasalahan di Papua. Konsekuensi dari status otonomi khusus Provinsi Papua dan Papua Barat mendapatkan kucuran dana fiskal dari pemerintah pusat setiap tahun. Data yang dihimpun dari Badan Pusat Statistik (BPS) mulai dari tahun 2002 - 2013 terjadi peningkatan Dana Otonomi Khusus (Dana Otsus) namun tidak diiringi dengan laju penurunan angka penduduk miskin (Imam \& Hafiz, 2019).

Semangat dari otonomi khusus sendiri justru diterapkan dengan tidak memperhatikan kondisi aktual di Papua. Digulirkannya otonomi khusus justru membuat masyarakat dihantui ketakutan, kekhawatiran, dan ketidakpastian. Terdapat ketakutan akan sumber daya alam yang dieksploitasi secara besar-besaran tanpa memperhatikan lingkungan dan tidak memberikan alasan aspek kemanfaatan bagi masyarakat setempat (Marit \& Warami, 2018). Praktis dari uraian diatas otonomi khusus belum mampu untuk menyelesaikan permasalahan di Papua. Sehingga dalam penelitian ini memiliki tujuan dan melakukan kajian analisa, diantaranya: Pertama melihat kendala dalam pelaksanaan otonomi khusus pada Papua dan Papua Barat. Kedua, rekomendasi terkait penyelesaian problematika pelaksanaan otonomi khusus yang terjadi di Papua dan Papua Barat. 
Sawala - Jurnal Administrasi Negara

ISSN: 2598-4039 (Online)

ISSN: 2302-2221 (Print)

Volume 9 Number 2 December 2021

Page $168-178$
Copyright (C) 2021, Jonathan Jacob Paul Latupeirissa,

I Putu Darma Wijaya, dan I Made Yuda Suryawan. This is an open access article under the CC-BY NC-SA

license

http:// DOI 10.30656/sawala.v9i2.3496 to this article

\section{METODE PENELITIAN}

Jenis penelitian yang digunakan adalah penelitian kualitatif. Dengan metode studi kasus terkait kebijakan otonomi khusus di Papua dan Papua Barat. Analisis data dilakukan dengan cara deskriptif analisis sehingga mampu mendeskripsikan secara terperinci dan jelas dalam fenomena sosial. Teknik pengumpulan data dilakukan dengan studi literatur seputar studi otonomi khusus, studi kebijakan publik, dan kajian ilmu politik. Analisis data difokuskan untuk memperdalam akar permasalahan di Papua dan Papua Barat sebagai bahan kajian pemberian rekomendasi yang tepat.

\section{HASIL DAN PEMBAHASAN}

\section{Kendala dalam Pelaksanaan Kebijakan Otonomi Khusus di Papua dan Papua Barat}

Untuk melihat sejauh mana dampak dari kebijakan Otonomi Khusus Papua dapat melihat indikator tingkat kesejahteraan masyarakatnya. Amanat dalam UU Otonomi Khusus terdapat 3 (tiga) hal mendasar yang menjadi urgensi dari penerapan kebijakan otonomi khusus, yaitu, Pertama, kewenangan antara pemerintah pusat dengan pemerintah daerah Provinsi Papua. Kedua, pengakuan penghormatan hak dasar masyarakat asli Papua. Ketiga, mewujudkan penyelenggaraan pemerintahan yang baik (Sakti \& Rukia, 2019). Namun urgensi dari ketiga dasar diatas masih jauh dari harapan. Hal tersebut terlihat mulai dari aspek perekonomian; pendidikan; indeks pembangunan manusia; dan pelayanan kesehatan, berikut gambaran pencapaian dari kebijakan otonomi khusus yang telah dicapai menurut (Fanggidae \& Fajri, 2016):

1. Aspek perekonomian. Data yang dihimpun dari BPS Papua Barat (2014), memperlihatkan bahwa mayoritas penduduk bekerja pada sektor pertanian sebesar $45,28 \%$; jasa $33,90 \%$, dan sebesar $61,59 \%$ berada pada bidang informal;

2. Aspek pendidikan. Sebenarnya dari tahun ke tahun terjadi peningkatan angka partisipasi sekolah. Namun, angka tersebut masih belum bagus, dan masih jauh kesenjangannya dari sekolah. Untuk Angka Partisipasi Sekolah (APS) untuk sekolah dasar (SD) sudah membaik, mencapai 92,76\%. Namun untuk tingkat sekolah menengah pertama (SMP) masih sebesar 62.29\%; sekolah menengah atas (SMA) sebesar 62,29\%; dan pada tingkat perguruan tinggi jauh lebih kecil hanya sebesar 24,19\%;

3. Aspek indeks pembangunan manusia (IPM). Tercatat IPM di Papua menempati urutan kedua terendah di Indonesia dengan nilai $61,82 \%$ dibawah rata-rata nasional sebesar $68,90 \%$;

4. Aspek pelayanan kesehatan. Pada tahun 2013 di Papua layanan kesehatan masih jauh dari ideal. Rasio jumlah dokter di Papua sebesar 1:7.599. Artinya 1 (satu) dokter ratarata melayani sekitar 7.559 orang. 
Sawala - Jurnal Administrasi Negara

ISSN: 2598-4039 (Online)

ISSN: 2302-2221 (Print)

Volume 9 Number 2 December 2021

Page $168-178$
Copyright (C) 2021, Jonathan Jacob Paul Latupeirissa,

I Putu Darma Wijaya, dan I Made Yuda Suryawan.

This is an open access article under the CC-BY NC-SA

license

http:// DOI 10.30656/sawala.v9i2.3496 to this article

Praktis apa yang dicita-citakan untuk meningkatkan kesejahteraan masyarakat di Papua masih jauh dari harapan. Sehingga diperlukan evaluasi terhadap jalannya kebijakan otonomi khusus, masih layak diteruskan atau diganti dengan kebijakan yang baru.

Peranan pemerintah dalam memberikan perhatian khusus ke pada Papua sebagai daerah dengan otonomi khusus belum sepenuhnya bisa diterapkan di Papua, hal ini dikarenakan kesiapan sumber daya yang memang jauh dari harapan. Dalam menjalankan dan mengelola kepemerintahannya, pemerintah daerah Papua masih di nilai kurang dalam berbagai aspek yang merujuk pada reformasi birokrasi.

Kebijakan Otonomi Khusus Papua justru mengarah kecenderungan meningkatkan ketidakpercayaan masyarakat kepada pemerintah. Berikut identifikasi masalah pelaksanaan Otonomi Khusus Papua yang dilaksanakan sejauh ini, diantaranya (Huda, 2014):

1. Uraian substansi dalam UU Otonomi Khusus Papua justru menambah perseteruan konflik yang berbuntut panjang antara masyarakat Papua dengan pemerintah. Seperti, masalah penggunaan lambang dan bendera daerah, Meskipun didalam UU Otonomi Khusus Papua memperbolehkan penggunaan lambang dan bendera, namun dalam praktiknya pemerintah pusat beberapa kali dihalang-halangi oleh pemerintah sendiri; 2. Praktik kebijakan penyelesaian konflik, lebih banyak pendekatan politiknya ketimbang upaya pembangunan dan peningkatan kesejahteraan masyarakat Papua. Kebijakan otonomi khusus lebih banyak diwarnai agenda-agenda politik seperti: pemekaran; demonstrasi; pengembalian otonomi khusus; dan agenda pilkada. Sarana untuk menutup jarak kesenjangan daerah Papua dengan daerah lain, perbaikan infrastruktur guna meningkatkan taraf kehidupan masyarakat Papua sangat sedikit;

3. Alokasi penyaluran dana otonomi khusus yang cepat tidak diiringi dengan tata laksana penggunaan dalam tujuan politik hukum dari pemberlakuan otonomi khusus. Penyaluran dana otonomi khusus telah dikeluarkan sejak tahun 2002, namun tidak ada satupun kerangka hukum yang menjamin dalam kebijakan penggunaan dana otonomi khusus tersebut. Peraturan Pemerintah tentang Majelis Rakyat Papua (MRP) baru disahkan setelah 3 (tiga) tahun pasca UU Otonomi Khusus diundangkan. Sama halnya dengan Peraturan Daerah Khusus (Perdasus) juga baru diterbitkan pasa 6 (enam) tahun setelah pengundangan UU Otonomi Khusus. Praktis, penyelenggaraan otonomi khusus tidak diiringi oleh kerangka hukum yang baik;

4. Tidak adanya proses evaluasi yang mendalam dan berjenjang. Evaluasi penyelenggaran otonomi khusus bersifat formalitas sehingga tidak mampu menghadirkan perbaikan dan pandangan yang komprehensif; 
Sawala - Jurnal Administrasi Negara

ISSN: 2598-4039 (Online)

ISSN: 2302-2221 (Print)

Volume 9 Number 2 December 2021

Page $168-178$
Copyright (C) 2021, Jonathan Jacob Paul Latupeirissa,

I Putu Darma Wijaya, dan I Made Yuda Suryawan. This is an open access article under the CC-BY NC-SA

license

http:// DOI 10.30656/sawala.v9i2.3496 to this article

5. Penyelenggaraan otonomi khusus tidak membumi sebab masyarakat Papua tidak semua memahami maksud dari otonomi khusus. Sehingga partisipatif masyarakat terhadap kebijakan otonomi khusus sangat rendah.

6. Pelanggaran HAM menjadi indikator kegagalan proses integrasi bangsa di Papua. Tata kelola pemerintah yang terjadi di Papua dengan pemerintah pusat sangat terbatas. Segungga kebijakan pemenuhan hak-hak dasar seperti lingkungan, pemberantasan kemiskinan, pelayanan air bersih, akses pendidikan, ekonomi, dan tindak kekerasan yang sering kali terjadi menjadi sulit untuk segera diselesaikan (Rochendi S \& Saleh, 2017).

\section{Rekomendasi Penyelesaian Problematika Otonomi Khusus di Papua dan Papua Barat}

Problematika di Papua dewasa ini perlu segera diselesaikan. Bentuk pendekatan penyelesaian harus mengedepankan cara-cara yang humanis, dan mengedepankan rasa kemanusian. Persoalan konflik masyarakat, demonstrasi, regulasi, pelanggaran HAM, kesenjangan ekonomi, dan minimnya fasilitas perlu segera dituntaskan. Berikut upaya kebijakan penyelesaian yang dapat ditempuh guna menyelesaikan konflik di Papua dari kebijakan otonomi khusus:

1. Pemerintah pusat perlu melakukan pengawasan dana otonomi khusus serta melakukan pemberantasan korupsi terkait penyelewengan dana yang diberikan. Hal ini dikarenakan dana otonomi khusus ditujukan untuk meningkatkan kesejahteraan rakyat di Papua (Imam \& Hafiz, 2019). Urgensi dari harapan untuk melakukan pengawasan daan agar dana yang dikucurkan dari pusat dapat diimplementasikan kepada program-program yang direncanakan. Pemerintah pusat dan daerah perlu mengkaji penggunaan dengan membuat grand design, atau master plan yang menjadi upaya pembangunan jangka panjang. Pengawasan ini menjadi penting untuk meminimalisir dari dari korupsi dan ketidakefektifan dana;

2. Menyelesaikan kasus-kasus pelanggaran HAM di Papua, serta memaksimalkan forum pendekatan penyelesaian konflik yang humanis dengan menjunjung nilai-nilai kemanusiaan. Kasus HAM di Papua menjadi pekerjaan rumah yang tak kalah penting untuk diselesaikan. Berdasarkan beberapa penelitian sebelumnya justru masyarakat Papua mulai skeptic, curiga, trauma akan bentuk kekerasan dan pemberlakukan otonomi khusus. Hal semacam ini terjadi di Aceh, ketika resolusi damai dan pemberian otonomi khusus gagal karena masyarakat mengalami beban psikis dari kekerasan, dan korban jiwa dalam berbagai peristiwa konfrontasi senjata;

3. Meningkatkan partisipasi, transparansi, akuntabilitas para pejabat di tingkat pemerintah pusat dan daerah dalam menjalankan kepentingan otonomi khusus (Ayunda, 2021). Prinsip ini sesuai dengan penyelenggaraan pemerintah dari perspektif good governance. Otonomi khusus pada esensi untuk masyarakat Papua, 
Sawala - Jurnal Administrasi Negara

ISSN: 2598-4039 (Online)

ISSN: 2302-2221 (Print)

Volume 9 Number 2 December 2021

Page $168-178$
Copyright (C) 2021, Jonathan Jacob Paul Latupeirissa,

I Putu Darma Wijaya, dan I Made Yuda Suryawan. This is an open access article under the CC-BY NC-SA

license

http:// DOI 10.30656/sawala.v9i2.3496 to this article

sehingga bentuk partisipasi masyarakat Papua menjadi tujuan utama. Partisipasi menjadi penting untuk meningkatkan gairah demokrasi lokal agar tidak dimonopoli oleh beberapa aktor politik yang ada. Lebih jauh lagi untuk mewujudkan bentuk transparansi, partisipasi, dan akuntabilitas diperlukan pembangunan SDM yang baik. Proyek-proyek pembangunan tidak hanya diupayakan hanya pembangunan fisik, namun juga kesempatan untuk membangun SDM masyarakat Papua.

Sementara itu dalam penyelesaian problematika otonomi khusus diperlukan bentuk tata kelola dari model pengelolaan dan penyelenggaran Otonomi Khusus Papua di masa depan yang lebih baik. Maka diperlukan role model penyelenggaran secara jangka panjang, diantaranya (Aziz et al., 2020):

\section{Model Penyelenggaraan Kewenangan Daerah}

Penyelenggaraan kewenangan kebijakan Otonomi Khusus Papua terdapat beberapa beberapa tahap dan pembagian kewenangan, diantaranya: Pertama, kewenangan pemerintah pusat. Urusan kewenangan pusat sendiri terdiri dari, politik hukum negeri; pertahanan keamanan; moneter dan fiskal nasional; agama; pembinaan daerah otonomi khusus/istimewa; dan pengawasan daerah otonomi khusus/istimewa. Kedua, urusan pemerintah daerah. Urusan pemerintah daerah diarahkan pada, membina, pengembangan adat dan budaya; kewenangan peradilan; pendidikan; kesehatan; dan kesejahteraan.

Sedangkan yang Ketiga, Harmonisasi Kewenangan. Dalam urusan harmonisasi kewenangan terdiri dari sinkronisasi perda khusus; penataan kewenangan pengawasan pengawasan di daerah; penataan kewenangan pemerintah dalam pengelolaan SDA yang adil dan demokratis. Keempat, Pembangunan Daerah. Dalam upaya pengelolaan otonomi khusus dalam pembangunan daerah selayaknya memiliki tujuan diantaranya: peningkatan kesejahteraan masyarakat; akselerasi pembangunan daerah; pembangunan berdasar karakter wilayah; perlindungan terhadap penduduk asli; dan urusan pendapatan dan kewenangan.

Untuk menjalankan konsep penyelenggaraan kewenangan daerah desentralisasi asimetris diperlukan harmonisasi dan sinkronisasi antara pemerintah pusat dan pemerintah daerah yang selaras. Sering kali pemerintah pusat justru memainkan peran kepada proses menjalankan kebijakan secara top down tanpa mengetahui kebutuhan masyarakat lokal. Dengan aspek kewenangan yang dimiliki selayaknya pemerintah pusat bersikap selaras dan mengoptimalkan pendekatan hubungan dengan pemerintah daerah yang baik, serta memiliki perencanaan yang baik.

\section{Model Penyelenggaraan Kelembagaan Daerah}

Model penyelenggaraan kelembagaan khusus yang ada di dalam daerah Otonomi Khusus Papua perlu memperhatikan beberapa hal, diantaranya: Pertama, 
Sawala - Jurnal Administrasi Negara

ISSN: 2598-4039 (Online)

ISSN: 2302-2221 (Print)

Volume 9 Number 2 December 2021

Page $168-178$
Copyright (C) 2021, Jonathan Jacob Paul Latupeirissa,

I Putu Darma Wijaya, dan I Made Yuda Suryawan. This is an open access article under the CC-BY NC-SA

license

http:// DOI 10.30656/sawala.v9i2.3496 to this article

Bentuk organisasi yang ramping dan efektif. Kelembagaan khusus tersebut harus efektif dalam penyelenggaran pemerintah daerah, meningkatkan peran check and balances dan support system executive. Kedua, rekruitmen anggota/sumber daya manusia. Upaya yang dapat ditempuh dengan menerapkan fit and proper test berdasarkan konteks kekhususan, dan standar minimal sebagai syarat keanggotaan kelembagaan khusus, misal tingkat pendidikan.

Ketiga, peran dan fungsi. Untuk menciptakan kelembagaan khusus di daerah otonomi khusus di Papua, seperti MRP/DPRP perlu dievaluasi dari sisi peran dan fungsinya, seperti: fungsi dan peran masing-masing lembaga; koordinasi antar lembaga khusus; dan memiliki fungsi legislasi, checks and balances, atau executive support. Keempat, inovasi dan keterbukaan informasi publik. Model inovasi dan keterbukaan informasi publik yang dimaksud, seperti: pemanfaatan teknologi informasi; evaluasi internal yang berkala; pelatihan SDM; pembinaan pusat; dan pelibatan masyarakat yang partisipatif bagi masyarakat Papua terhadap penyelenggaraan otonomi khusus.

Peran penting dari keberadaan lembaga khusus peluang dan ruang kepada entitas lokal untuk berpartisipasi dalam pemerintah desentralisasi asimetris. Lembaga khusus ini diharapkan menjadi lembaga yang dekat dengan masyarakat. Namun, dalam menjalankan kelembagaan khusus ini diperlukan kajian tentang keefektifan dalam pemerintah daerah. Disamping untuk mengakomodir potensi atau aspek kekhususan namun, diperlukan SDM, tujuan, dan fungsi yang benar-benar memberikan dampak kepada jalannya pemerintah daerah yang berlangsung.

\section{Model Penyelenggaran Keuangan}

Model penyelenggaran keuangan di daerah otonomi khusus memiliki cara yang berbeda. Oleh karena itu diperlukan model penyelenggaraan keuangan yang dikelola oleh daerah Otonomi Khusus Papua, seperti: Pertama, penyiapan rencana induk. Perencanaan yang dimaksud diantaranya: peningkatan kapasitas SDM (eksekutif dan legislatif), dan pelibatan peran eksekutif, legislatif serta partisipatif masyarakat Papua. Kedua, penyiapan regulasi. Penyiapan regulasi dilakukan dengan melakukan peningkatan kapasitas SDM; penguatan peran lembaga khusus; dan pelibatan DPRD.

Ketiga, mekanisme penyaluran dana. Mekanisme penyaluran dana otonomi khusus dapat dilakukan dengan, transfer dana secara langsung dari pusat ke daerah; penguatan terhadap korbinwas di daerah provinsi hingga ke daerah kabupaten; dan pemerintah daerah wajib penggunaan dana otonomi khusus. Keempat, jangka waktu pemberian dana. Untuk proses pemberian dana otonomi khusus diperlukan sebuah jangka, seperti: ada batasan sebagaimana sekarang 20 tahun; setelah 20 tahun diperlukan evaluasi akan dilanjutkan atau tidak; dan evaluasi berkala tentang pemberian dana otonomi khusus dari pemerintah pusat dan pemerintah daerah. 
Sawala - Jurnal Administrasi Negara

ISSN: 2598-4039 (Online)

ISSN: 2302-2221 (Print)

Volume 9 Number 2 December 2021

Page $168-178$
Copyright (C) 2021, Jonathan Jacob Paul Latupeirissa,

I Putu Darma Wijaya, dan I Made Yuda Suryawan. This is an open access article under the CC-BY NC-SA

license

http:// DOI 10.30656/sawala.v9i2.3496 to this article

\section{Model Penyelenggaraan Politik dan Pemerintah}

Untuk penyelenggara politik dan pemerintahan di daerah Otonomi Khusus Papua secara baik maka diperlukan beberapa tahapan: Pertama, pembentukan partai lokal yang berkualitas. Upaya tersebut dapat dilakukan dengan diantaranya, diperlukan SDM partai lokal yang berkualitas; menjalankan sebagai pengatur konflik; mengedepankan cara-cara demokratis dalam bersaing; dan tidak mengancam kedaulatan NKRI. Kedua, menyelenggarakan pemerintahan lokal yang kapabel, efisien, dan sinergis. Ketiga, penyelenggara penggunaan simbol khusus yang bersifat historis-filosofis, representatif, dan harus diterima semua pihak. Keempat, peran aktor mampu mendorong percepatan laju demokratis yang mencerdaskan masyarakat.

Untuk menjalankan penyelenggaraan politik dan pemerintah daerah diperlukan niat yang ditujukan untuk mensejahterakan kepentingan daerah. Hal tersebut karena menjadi sebuah esensi dari pemberlakuan otonomi khusus. Praktik yang terjadi selama ini terjadi pergeseran nilai-nilai, bahwa penyelenggaraan pemerintah justru banyak dinikmati oleh segelintir tokoh politik. Masyarakat yang seharusnya menjadi objek utama dari sasaran kesejahteraan justru kian ditinggalkan. Terlebih lagi implementasi dari otonomi khusus sendiri kurang dirasakan oleh masyarakat lokal. Kebijakan otonomi khusus dalam perihal politik seharusnya tidak sekedar menjadi slogan namun benar-benar membumi dan diketahui oleh masyarakat secara luas.

\section{Model Penyelenggaraan Koordinasi, Pembinaan, dan Pengawasan}

Sedangkan terkait model penyelenggaraan koordinasi, pembinaan, dan pengawasan diperlukan sistem dari internal dan eksternal. Sistem tersebut dapat dilakuan dengan cara diantaranya: membentuk sinergitas pengawasan di pusat dan di daerah; peningkatan peran dan fungsi anggota dewan; memperkuat peran biro/lembaga khusus; meningkatkan peran serta pelibatan masyarakat; dan evaluasi secara berkala.

Segala kebijakan otonomi khusus di Papua mulai dari kebijakan politik, fiskal, ekonomi, pembangunan, perlu dilakukan penyelenggaraan koordinasi, pembinaan, dan pengawasan yang baik. Yang terjadi dewasa ini pemberian otonomi khusus yang sudah berumur 20 tahun tanpa ada sebuah evaluasi yang jelas. Pemerintah daerah justru mengalihkan kepada aspek-aspek diluar dari implementasi otonomi khusus yang konsekuen. Diperlukan grand design yang ideal dalam mewujudkan otonomi khusus yang ideal.

\section{SIMPULAN}

Kebijakan otonomi khusus di Papua justru meningkatkan kecurigaan dan ketidakpercayaan masyarakat. Implementasi otonomi khusus dirasa tidak membumi dan kurang dimengerti oleh masyarakat secara umum. Hal ini dikarenakan pemerintah 
Sawala - Jurnal Administrasi Negara

ISSN: 2598-4039 (Online)

ISSN: 2302-2221 (Print)

Volume 9 Number 2 December 2021

Page $168-178$
Copyright (C) 2021, Jonathan Jacob Paul Latupeirissa,

I Putu Darma Wijaya, dan I Made Yuda Suryawan. This is an open access article under the CC-BY NC-SA

license

http:// DOI 10.30656/sawala.v9i2.3496 to this article

sendiri membuat kebijakan yang kontra produktif yang justru menghalang-halangi dari pelaksanaan otonomi khusus. Pihak kelompok pro-kemerdekaan dan sebagian masyarakat

Untuk mengatasi problematika tersebut diperlukan penyelesaian yang terjadi dewasa ini, dan membentuk re-desain model penyelenggaraan otonomi khusus di masa depan yang ideal. Tahap pertama perlu melakukan penyelesaian problematika otonomi khusus, yaitu, (1) dengan melakukan pengawasan dana otonomi khusus guna meminimalisir penyalahgunaan; (2) penyelesaian kasus pelanggaran HAM; dan (3) meningkatkan partisipasi, transparansi, dan akuntabilitas para pemangku jabatan penyelenggara otonomi khusus. Tahap kedua dengan mengusulkan konsep penyelenggaraan otonomi khusus kedepan, dengan menjalan beberapa model, yaitu, (1) model kewenangan otonomi khusus; (2) model kelembagaan khusus otonomi khusus; (3) model penyelenggaraan politik pemerintah; (4) model penyelenggaraan keuangan; dan (5) model pelaksanaan koordinasi, pembinaan, pengawasan daerah otonomi khusus. Pasca pemberlakuan otonomi khusus sebenarnya bukan menjadi akhir dari perhatian pemerintah kepada Papua. Fokus yang diberikan selayaknya memberikan evaluasi dan perbaikan praktek otonomi khusus di Papua.

\section{DAFTAR PUSTAKA}

Alivia, D. (2019). Politik Hukum Pengaturan Pemerintahan Daerah yang Bersifat Khusus atau Bersifat Istimewa di Indonesia. Rechtsidee, 14(2), 150-166.

Ayunda, R. (2021). Dampak Riil Implementasi Status Otonomi Khusus di Provinsi Papua, Indonesia: Kajian Hukum Perspektif Good Governance. Jurnal Komunikasi Hukum, $7(1), 387-402$.

Aziz, L. L. N., Zuhro, S. R., Cahyono, H., Suryani, D., \& Maulana, Y. (2020). Model Desentralisasi Asimetris dalam NKRI (L. L. N. Aziz \& S. R. Zuhro (eds.); 1st ed.). Yayasan Pustaka Obor Indonesia.

Fanggidae, I. G., \& Fajri, H. (2016). Menelisik Kinerja Governance di Daerah Otonomi Khusus Papua Barat. Natapraja: Jurnal Kajian Ilmu Administrasi Negara, 4(1), 91-106. Huda, N. (2014). Desentralisasi Asimetris Dalam NKRI (1st ed.). Nusamedia.

Imam, R., \& Hafis, A. (2019). Desentralisasi Asimetris: Kemiskinan Di Tengah Kelimpahan Otonomi Khusus Papua. Jurnal Penelitian Administrasi Publik, 5(2), 11801192.

Jamal, O., \& Mara, S. (2018). Politik Kewargaan Multikulturalisme : (Studi Kasus Tentang Peran Majelis Rakyat Papua dalam Memperjuangkan Kepentingan Masyarakat Adat Papua Era Otonomi Khusus ). Jurnal Politik \& Pemerintahan, 2(2), 156-164.

Kharisma, V. D., Samputra, P. L., \& Muntaha, P. Z. (2020). Analisis Dampak Kebijakan Alokasi Dana Otonomi Khusus Bidang Pendidikan dan Kesehatan Terhadap Indeks 
Sawala - Jurnal Administrasi Negara

ISSN: 2598-4039 (Online)

ISSN: 2302-2221 (Print)

Volume 9 Number 2 December 2021

Page $168-178$
Copyright (C) 2021, Jonathan Jacob Paul Latupeirissa,

I Putu Darma Wijaya, dan I Made Yuda Suryawan.

This is an open access article under the CC-BY NC-SA

license

http:// DOI 10.30656/sawala.v9i2.3496 to this article

Pembangunan Manusia di Provinsi Papua. Jurnal Public Uho, 3(1), 1-20. https://doi.org/10.35817/jpu. v3i1.11392

Marit, E. L., \& Warami, H. (2018). Wacana "Papua Tanah Damai” dalam Bingkai Otonomi Khusus Papua. Jurnal Ilmu Sosial, 16(1), 41-46.

Mustikawati, R., \& Maulana, A. (2020). Provinsi Papua Sebelum dan Setelah 18 Tahun Pemberian Dana Otonomi Khusus. Jurnal Public Policy,2(6),82-98.https:// doi.org/https://doi.org/10.35308/jpp.v6i2.2401

Nyimas Latifah Letty Aziz, T. (2018). Pola Pengawasan Pengelolaan Dana Otonomi Khusus dan Istimewa: Perspektif Politik. Jurnal Penelitian Politik, 15(726), 81-96.

Pratomo, R. R. (2021). Sosialisasi Tentang Dampak Otonomi Khusus dan Potensi Pemekaran Wilayah Papua Kepada Masyarakat Umum. Jurnal Pengabdian Masyarakat (JMP), 1(1), 28-35.

Rochendi S, \& Saleh, K. A. (2017). Hubungan Pemerintah Pusat dan Daerah Dalam Otonomi Khusus di Provinsi Papua Barat. Jurnla Kajian Politik Dan Masalah Pembangunan, 13(1), 1903-1919.

Sakti, A., \& Rakia, R. (2019). Kewenangan Khusus Majelis Rakyat Papua Terhadap Pembentukan Perdasus. Jurnal Justisi, 7(1), 14-25.

Suryani, D., Zuhro, S. R., Cahyono, H., Aziz, L. L. N., Aulia, D., \& Maulana, Y. (2020). Aktor di Balik Tuntutan Otonomi Khusus Studi Kasus Bali dan Maluku Utara (D. Suryani \& S. R. Zuhro (eds.); 1st ed.). Yayasan Pustaka Obor Indonesia. 